\title{
Osteochondroma of the condyle: case report and a conservative alternative for
}

\section{surgical approach}

\author{
Osteocondroma condilar: relato de caso e uma alternativa conservadora de acesso cirúrgico \\ Osteocondroma del cóndilo: informe de un caso y una alternativa conservadora para el abordaje \\ quirúrgico
}

Received: 08/09/2021 | Reviewed: 08/15/2021 | Accept: 08/28/2021 | Published: 08/30/2021

\author{
Matheus Herreira-Ferreira \\ ORCID: https://orcid.org/0000-0002-2829-9505 \\ State University of Maringá, Brazil \\ E-mail: matwzferreira@gmail.com \\ Gustavo Nascimento de Souza-Pinto \\ ORCID: https://orcid.org/0000-0002-6509-4998 \\ State University of Maringá, Brazil \\ E-mail: nsouzagustavo@gmail.com \\ Lilian Crsitina Vessoni Iwaki \\ ORCID: https://orcid.org/0000-0002-1822-3056 \\ State University of Maringá, Brazil \\ E-mail: lilianiwaki@gmail.com \\ Liogi Iwaki-Filho \\ ORCID: https://orcid.org/0000-0001-9117-6826 \\ State University of Maringá, Brazil \\ E-mail: liogifilho@gmail.com
}

\begin{abstract}
Osteochondroma (OC) is one of the most common benign tumors of bone but is rarely found in the mandibular condyle. The aim of this case report is to demonstrate condylectomy through endaural approach (EA) as a conservative alternative for the treatment of the OC. A 60-year-old woman having an OC of 23 millimeters length in the mandibular condyle. The patient underwent a surgical procedure for tumor resection. To generate less morbidity, a conservative approach was performed.
\end{abstract}

Keywords: Osteochondroma; Endaural approach; Condylectomy; Benign tumor; Temporomandibular joint.

\section{Resumo}

O osteocondroma (OC) é um dos tumores benignos ósseos mais comuns, porém, raramente encontrado na cabeça da mandíbula. O objetivo deste relato de caso é apresentar uma condilectomia através de um acesso endaural (AE) como uma alternativa conservadora para o tratamento do OC. Uma paciente do sexo feminino, de 60 anos, apresentando um OC de 23 milimetros de comprimento na cabeça da mandíbula. A paciente foi submetida a um procedimento cirúrgico para ressecção tumoral. A fim de gerar menos morbidade, um acesso conservador foi realizado.

Palavras-chave: Osteocondroma; Acesso endaural; Condilectomia; Tumor benigno; Articulação temporomandibular.

\section{Resumen}

El osteocondroma (OC) es uno de los tumores benignos más comunes del hueso, pero rara vez se encuentra en el cóndilo mandibular. El objetivo de este informe de caso es demostrar la condilectomía a través del abordaje endaural (EA) como una alternativa conservadora para el tratamiento del OC. Una mujer de 60 años que presentó un CO de 23 milímetros de longitud en el cóndilo mandibular fue sometida a un procedimiento quirúrgico para la resección del tumor. Para generar menos morbilidad, se realizó un enfoque conservador.

Palabras clave: Osteocondroma; Abordaje endoscópico; Condilectomia; Tumor benigno; Articulación temporomandibular.

\section{Introduction}

One of the most complex articulation, the temporomandibular joint (TMJ), is composed by mandibular condyle and the mandibular fossa and is located in temporal bone (Giozet et al., 2019; Grossmann et al., 2016; Pinto et al., 2019). Therefore, the joint environment can be affected by neoplasia (Wright \& Vered, 2017). 
Osteochondroma (OC) is a benign bone tumor and the most common of the primary tumors (Wolford et al., 2002; Yang et al., 2015). The OC, also known as osteocartilaginous exostosis, has undefined etiology, characterized by its intramembranous origin and predilection for long bones, which makes it rare to occur at mandibular condyle and coronoid process (Yang et al., 2015). Clinically, the presence of the OC in the mandibular condyle leads to facial asymmetry, malocclusion, temporomandibular disorders, even pain and hearing problems (Ward et al., 2005; Yang et al., 2015). The OC of the mandibular condyle is normally treated by condylectomy (Roychoudhury et al., 2011; Wolford et al., 2002).

The purpose of this paper is to present a case report and a conservative alternative for the surgical access of the condylectomy for the OC through an endaural approach (EA).

\section{Case Report}

A 60-year-old female patient was referred to a private clinic complaining of pain, cracking in the left temporomandibular joint (TMJ) and progressive facial asymmetry, with an estimated 5-year evolution time. The patient presented in good general health and no previous trauma and syndrome history was reported. In the opened mouth, the patient showed mandibular limited deflection to the left side, and increased volume in the TMJ, ipsilaterally. In the intraoral examination, upper and lower dentures with a unilateral posterior open bite on the left side were noted.

A cone beam computed tomography ( $\mathrm{CBCT}$ ) was requested and a morphological alteration on the left mandibular condyle was observed. The CBCT showed a hyperdense image with a globular shape, emerging from the upper condyle. The cortical bone demonstrated degenerative signs (erosion) (Figure 1A). Bone scintigraphy was performed, and intense osteoblastic activities were detected only in the left TMJ. The diagnostic hypothesis comprised was OC, with approximately 23 millimeters length (Figure 1B).

Figure 1. A - Coronal CBCT view showing an extensive bony mass on the left side of the mandibular condyle. B - Axial $\mathrm{CBCT}$ view showing the dimensions of the tumor.

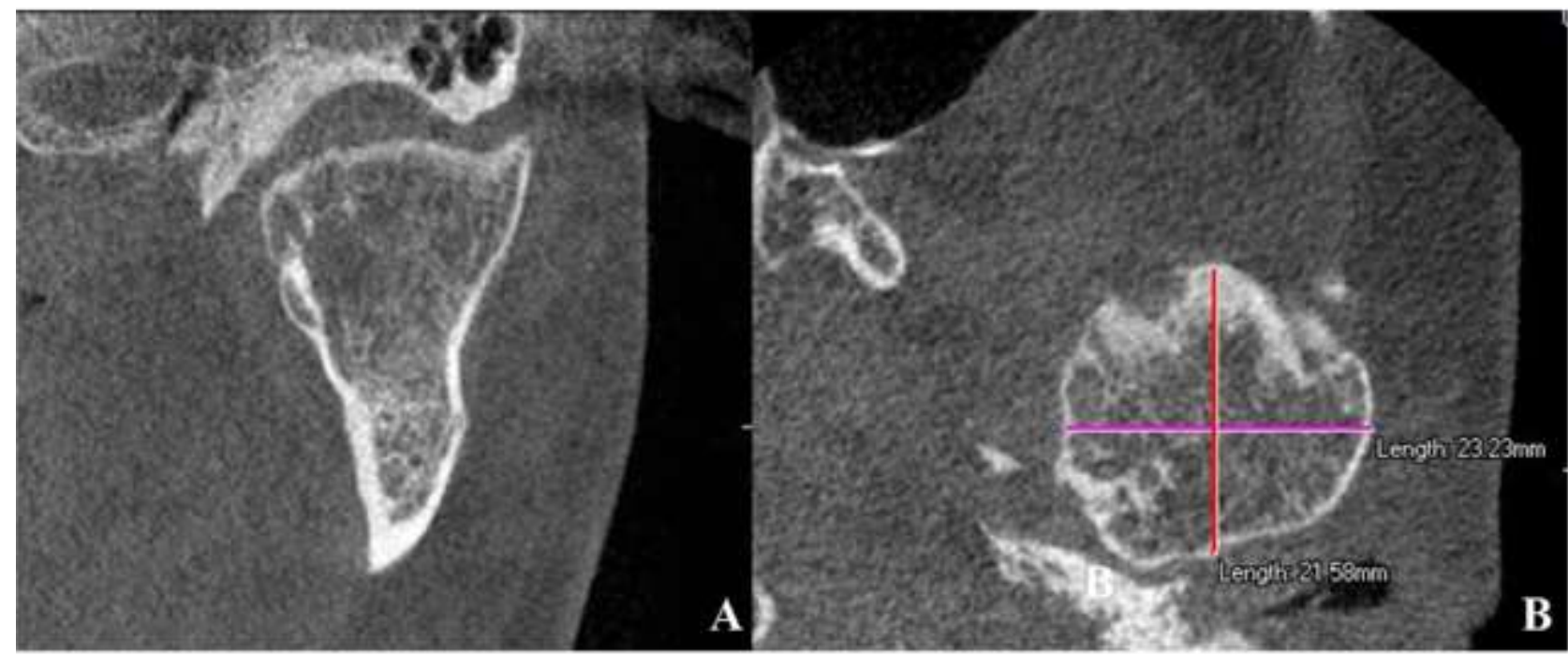

Source: Authors.

Based on clinical and imaging findings, a conservative approach to condylectomy was performed by EA on the left side. Nasotracheal intubation was performed, and the tumor was removed through piezoelectric bone surgery (Figure 2A). Due to the minimally invasive approach, the tumor had to be removed in small fragments (Figures 2B, C), carefully to avoid any damage to noble structures, such as arteries, facial nerve, muscles, and parotid gland. The recontouring of the condylar neck 
and an articular disc repositioning over the recontoured condylar stump were also performed. After the surgical procedure, the histopathological examination confirmed an OC, with islands of hyaline cartilaginous tissue, scattered throughout the underlying ossification plates with mature trabecular bone, without cellular atypia.

Figure 2. A - Tumor access through piezoelectric bone surgery. B - Endaural approach to remove fragments of the osteochondroma. C - Fragments of the tumor. D - Final aspect of Endaural approach.

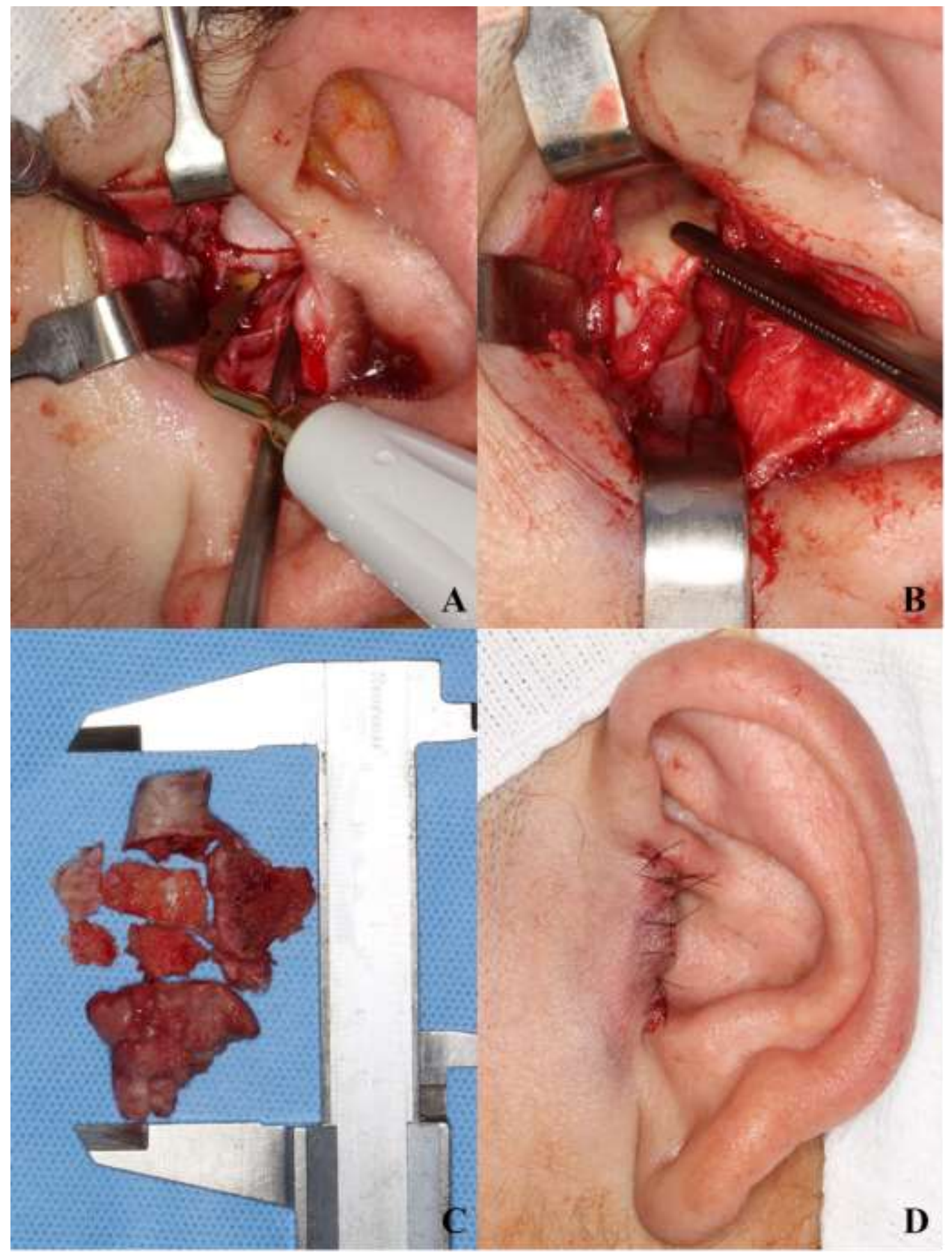

Source: Authors.

In the postoperative, the patient received rest instructions and physiotherapy exercises for opening and closing movements of the mouth. To restore the dental occlusion, oral rehabilitation was performed. In the 1-year follow-up, the 
patient presented a good mouth opening with slight mandibular deflection to the affected side, without any aesthetic complaints. All ethical issues involving the case report were respected, and express authorization was obtained from the patient.

\section{Discussion}

The OC is the most common benign bone tumor (Wolford et al., 2002; Yang et al., 2015), characterized as a lesion that arises from the cortex of the bone and is capped with cartilage (Chen et al., 2014; Fan et al., 2014). Being more frequent in the female gender and without predilection for age (Peroz, 2016), tends to occur at a later age in the jaws than long bones (Ord et al., 2010). In general, the OC has an anteriormedial or anteriorsuperior growth trend (Chen et al., 2014; Yang et al., 2015), nevertheless, growth can occur in any direction (Peroz, 2016). Clinically, the patient may present TMJ pain/dysfunction, asymmetry, malocclusion with mandibular deflection to the contralateral side, with an ipsilateral open bite (Ord et al., 2010; Roychoudhury et al., 2011).

Some surgical techniques for the OC treatment were described in the literature. However, the size of the tumor and its impact on the patient is fundamental to the choice of the surgical technique (Peroz, 2016). In this case, a conservative condylectomy through an EA was chosen, below the head but overhead in the neck of the mandibular condyle, respecting the margins of the tumor, as recommended by Wolford et al., 2002 (Wolford et al., 2002). A piezoelectric cutting device was used due to its capacity of less invasion and safety (Chiarini et al., 2014; Gonzalez-Lagunas, 2017). This technique for the treatment of mandibular condyle OC permits adequate removal of the pathology while maintaining native mandibular bone and the articular disc within the TMJ eliminating the need for grafts, and thereby, decreases patient morbidity (Wolford et al., 2002). Also, this technique showed no recurrence (Roychoudhury et al., 2011).

To the best of our knowledge, there are only two successful cases reported in the literature of OC removed by EA (Bachesk et al., 2020; Lim et al., 2014). The most common surgical accesses reported are preauricular, preauricular with extended temporal and submandibular/Risdon approach (Ord et al., 2010; Roychoudhury et al., 2011; Yang et al., 2015). Despite the predominance of these approaches, several additional complications have been reported, and it also leaves a visible scar along its entire length (Santos et al., 2014). However, in the present case the EA was chosen and demonstrated excellent outcomes. The EA promotes direct access to the lesion and adequate protection, minimizing injuries to noble structures and provides excellent aesthetic outcomes (Bachesk et al., 2020; Santos et al., 2014). Since the OC tends to be self-limiting and the treatment of the tumor depends on the size, symptoms and growth status (Roychoudhury et al., 2011).

\section{Final Considerations}

The authors encourage the surgeons to resort to EA when the OC is presented symptomatic, restricted only to the mandibular condyle, especially when there is no need for orthognathic surgery, grafts, or joint prosthesis.

\section{References}

Bachesk, A. B., Sessenta Junior, C. F., \& Iwaki Filho, L. (2020). Surgical resection of osteochondroma in the mandibular condyle associated with directional orthodontic treatment: review of literature and a case report. Oral Surgery, 13(3), 280-290. https://doi.org/10.1111/ors.12493

Chen, M. J., Yang, C., Qiu, Y. T., Zhou, Q., Huang, D., \& Shi, H. M. (2014). Osteochondroma of the mandibular condyle: A classification system based on computed tomographic appearances. Journal of Craniofacial Surgery, 25(5), 1703-1706. https://doi.org/10.1097/SCS.0000000000000898

Chiarini, L., Albanese, M., Anesi, A., Galzignato, P. F., Mortellaro, C., Nocini, P., \& Bertossi, D. (2014). Surgical treatment of unilateral condylar hyperplasia with piezosurgery. Journal of Craniofacial Surgery, 25(3), 808-810. https://doi.org/10.1097/SCS.0000000000000699

Fan, H., Lv, X., Shi, J., Hu, J., \& Luo, E. (2014). One-stage treatment to osteochondroma of the coronoid process and secondary facial asymmetry with coronoidectomy and reduction malarplasty: A case report and literature review. Journal of Oral and Maxillofacial Surgery, 72(9), 1870.e1-1870.e13. 
Research, Society and Development, v. 10, n. 11, e247101119216, 2021

(CC BY 4.0) | ISSN 2525-3409 | DOI: http://dx.doi.org/10.33448/rsd-v10i11.19216

https://doi.org/10.1016/j.joms.2014.04.030

Giozet, A. F., Iwaki, L. C. V., Grossmann, E., Previdelli, I. T. S., Pinto, G. N. de S., \& Iwaki Filho, L. (2019). Correlation between clinical variables and magnetic resonance imaging findings in symptomatic patients with chronic temporomandibular articular disc displacement with reduction: A retrospective analytical study. Cranio - Journal of Craniomandibular Practice, 37(6), 374-382. https://doi.org/10.1080/08869634.2018.1449360

Gonzalez-Lagunas, J. (2017). Is the piezoelectric device the new standard for facial osteotomies? Journal of Stomatology, Oral and Maxillofacial Surgery, 118(4), 255-258. https://doi.org/10.1016/j.jormas.2017.06.009

Grossmann, E., Remedi, M. P., Ferreira, L. A., \& Carvalho, A. C. P. (2016). Magnetic resonance image evaluation of temporomandibular joint osteophytes: Influence of clinical factors and artrogenics changes. Journal of Craniofacial Surgery, 27(2), 334-338. https://doi.org/10.1097/SCS.0000000000002377

Lim, W., Weng, L., \& Tin, G. (2014). Osteochondroma of the mandibular condyle: Report of two surgical approaches. Annals of Maxillofacial Surgery, 4(2), 215. https://doi.org/10.4103/2231-0746.147151

Ord, R. A., Warburton, G., \& Caccamese, J. F. (2010). Osteochondroma of the condyle: review of 8 cases. International Journal of Oral and Maxillofacial Surgery, 39(6), 523-528. https://doi.org/10.1016/j.ijom.2010.02.015

Peroz, I. (2016). Osteochondroma of the condyle: case report with 15 years of follow-up. International Journal of Oral and Maxillofacial Surgery, 45(9), 1120-1122. https://doi.org/10.1016/j.ijom.2016.04.005

Pinto, G. N. de S., Grossmann, E., Iwaki Filho, L., Groppo, F. C., Poluha, R. L., Muntean, S. A., \& Iwaki, L. C. V. (2019). Correlation between joint effusion and morphology of the articular disc within the temporomandibular joint as viewed in the sagittal plane in patients with chronic disc displacement with reduction: A retrospective analytical study from magnetic resonance. Cranio®, Feb 21, 1-6. https://doi.org/10.1080/08869634.2019.1582166

Roychoudhury, A., Bhatt, K., Yadav, R., Bhutia, O., \& Roychoudhury, S. (2011). Review of osteochondroma of mandibular condyle and report of a case series. Journal of Oral and Maxillofacial Surgery, 69(11), 2815-2823. https://doi.org/10.1016/j.joms.2010.10.016

Santos, G. S., Nogueira, L. M., Sonoda, C. K., \& Melo, W. M. de. (2014). Using Endaural Approach for Temporomandibular Joint Access. The Journal of Craniofacial Surgery, 25(3), 1142-1143.

Ward, B. B., Pires, C. A. S., \& Feinberg, S. E. (2005). Osteochondromas of the mandible: Case reports and rationale for treatment. Journal of Oral and Maxillofacial Surgery, 63(7), 1039-1044. https://doi.org/10.1016/j.joms.2005.03.022

Wolford, L. M., Mehra, P., \& Franco, P. (2002). Use of conservative condylectomy for treatment of osteochondroma of the mandibular condyle. Journal of Oral and Maxillofacial Surgery, 60(3), 262-268. https://doi.org/10.1053/joms.2002.30570

Wright, J. M., \& Vered, M. (2017). Update from the 4th Edition of the World Health Organization Classification of Head and Neck Tumours: Odontogenic and Maxillofacial Bone Tumors. Head and Neck Pathology, 11(1), 68-77. https://doi.org/10.1007/s12105-017-0794-1

Yang, X. H., Zhang, P., Xu, J. H., \& Hu, Y. J. (2015). An osteochondroma of the mandibular condyle. Journal of Craniofacial Surgery, 26(2), 567-569. https://doi.org/10.1097/SCS.0000000000001331 